\title{
EFFECT OF LACTATION PERIOD ON THE CHEMICAL AND FATTY ACIDS COMPOSITION OF BREAST MILK IN MOSUL CITY
}

\author{
Abdullah M. Thannoun* Adnan I. Abbo**
}

*Food Sci. \& Biotech. Dept.,Coll. of Agric. and Forestry, Mosul University, Iraq.

** Foundation of Technical Institutes, Mosul Technical Institute, Mosul, Iraq.

\begin{abstract}
The effect of Lactation period (Infant age) on the chemical and fatty acids composition of breast milk including colostrum in Mosul city was studied. Three hundred and eighty nine normal samples of human (breast) milk of healthy lactating mothers of 17 to 46 years of age nurturing infants starting from the birthday $\left(1^{\text {st }}\right.$ day of infants age for colostrum) until 2.5 years of age were collected from five area in Mosul city and Al-khansaa delivery hospital. Thirty of the above subjects were chosen as volunteers to give constant periodically and monthly breast milk samples for fatty acid analysis. Results show that there was an effect of lactation period on the fat, protein, lactose and ash \% of the breast milk. Fat and lactose \% were increased, whereas, protein and ash \% decreased with lactation period. Generally, there was no significant $(\mathrm{P}<0.05)$ effect of lactation period on the Saturated fatty acid (SFA) and Polyunsaturated fatty acid (PUFA) although, there was slight increased in both SFA and PUFA \% with lactation period. PUFA/SFA ratio was also not affected. It was concluded that the components such as fat, protein and lactose of human milk might be influenced by lactation period.
\end{abstract}

\section{INTRODUCTION}

Since the nutritional requirements of the infants are based on composition of milk, human milk is the only natural food known as the best form of nutrition for the neonates and infants for the first months of life. Exclusive breast-feeding by well-nourished mothers can be adequate for periods varying from 2 to 15 months (Williams, 1985). Consequently, the milk slowly loses its dominant role in the infant feeding even that it should stay the crucial in the diet. Human milk, in addition to its numerous nutrients ideal for the growing term infant, is a bioactive fluid that evolves as the infant matures, from colostrum to mature milk (Wagner, 1999). However, the composition of breast milk is not uniform, and the concentrations of many of its constituents change during the lactation period and differ among individual mothers (Prentice, 1996). Usually, more changes in the fat and protein of the breast milk are occurred during the lactation period (Harzer et al., 1983; Ferris et al., 1988 and Georgy and Swatzki, 1994). Generally, breast milk composition is not constant and varies with stage of lactation, breastfeeding pattern, season, and parity and also differs among individuals and among communities, for reasons that are not well understood (Prentice, 1996 and Bishara et al., 2008). Gurr (1981) referred that differences in the composition of the milk throughout the lactation period is very important in the regulation of the nutrients requirements of the infant especially protein. Previous to that, Eidelman (1980) reviewed that milk from mothers of preterm infants as compared to milk from mothers of term infants

Part of $\mathrm{PhD}$ Thesis of the $2^{\text {nd }}$ author.

Received 10/3/2009 accepted 25/6/2009 
more readily meets the special nutritional requirements of the preterm infant. Moreover, he added that this is true even when milk from mothers of the same postpartum age is compared and is particularly striking when one analyses for the constituents of the milk such as protein, sodium, calcium, and polyunsaturated fatty acid content. More recently, Mandel et al. (2005) found that human milk expressed by mothers who have been lactating for $>1$ year has significantly increased fat and energy contents, when compared with milk expressed by women who have been lactating for shorter periods. Noticeable changes in saturated (SFA), Monounsaturated (MUFA), and Polyunsaturated fatty acids (PUFA) of the breast milk during the lactation period were also found by Guesnet et al. (1993) and Jackson et al. (1993). Although numerous studies have been performed on the differences in the composition of the human milk, the general profile of its constituents is the same. However, Knowledge of the composition of human milk and the factors that influence it has increased considerably over the past decade. The aim of this study was performed to determine the possible changes in chemical composition and fatty acids of breast milk during the lactation period of the mothers in Mosul city.

\section{MATERIALS AND METHODS}

Subjects Selection: Three hundred and eighty nine normal samples of human (breast) milk of healthy lactating mothers of 17 to 46 years of age nurturing infants starting from the birthday ( $1^{\text {st }}$ day of infants age for colostrum) until 2.5 years of age for period of November, 1998 to October, 1999 were collected from five area in Mosul city and Al-khansaa delivery hospital. Corresponding, all types of milk were collected among this period and this range of infant's age, namely, colostrum, transitional milk and mature milk. Thirty of the above subjects were chosen as volunteers to give constant periodically and monthly breast milk samples for fatty acid analysis. Mothers who met these criteria were interviewed and anthropometrical measurements, historical data, and dietary recall that emphasized the nutritional status were taken using a standard questionnaire. Food sufficiency status and their quality and food nutrients density of mothers if the food eaten by them and/or their families were determined.

Samples collection: About 5 to $30 \mathrm{ml}$ samples of breast milk were taken using sterilized hand breast pump or sucker. The samples were kept in sterilized well sealed glass bottles and stored in refrigerator at $5^{\circ} \mathrm{C}$ until analysis. Milk samples for fatty acid analysis were immediately lipids extracted using organic solvents and the lipids extract was kept in dry well sealed tubes and stored in freezer at $-18^{\circ} \mathrm{C}$ until next step of analysis.

Chemical Analysis: Moisture, protein, fat, lactose, ash and $\mathrm{pH}$ of the milk samples were determined. Moisture was determined according to the method of Russell and Gray (1979). Protein was determined according to the method of Lowry et al. (1951) and Miller (1959) which was modified by Georgy and Robert (1973) using bovine albumin as standard. Fat was determined by Gerber method which was mentioned by Ling (1963). Lactose was determined by method described by Plummer (1978) and Al-Sarrajy (1986) using 3, 5-Dinitrosalycilic acid (DNS). Ash 
was determined according to the method of Ling (1963) which was described by Ali (1989).

Fatty acids determination: Lipids extraction was performed using method of Majonnier which was described by Walstra and DeGraff (1962) and modified by Al-Fayadh (1973) and Mohammad (1978). Ten ml of milk were taken in $100 \mathrm{ml}$ separatory funnel containing $0.15 \mathrm{~g} \mathrm{NaCl}$ and shacked vigorously for 30 seconds. Then $1.5 \mathrm{ml}$ of concentrated ammonia solution was added and shacked again for 30 seconds then $10 \mathrm{ml}$ of $95 \%$ of ethanol and shacked for one min. Twenty five $\mathrm{ml}$ of diethyl ether were added to the mixture and shacked for one min. before addition of another $25 \mathrm{ml}$ of petroleum ether and shacked then leaving the solution to settle down for $30 \mathrm{~min}$. to separate the lipids layer. Lipids extracted solution was transferred to the flask of rotatory evaporator for evaporation of the solvents at $50^{\circ} \mathrm{C}$. The lipid samples were placed in well sealed vials and stored in freezer at $18^{\circ} \mathrm{C}$ until another step. Triglycerides isolation: Triglycerides were isolated according to the method described by Al-Hubaity (1997) using isolation column of silica gel and using chloroform and the benzene as an element. After isolation the solvents were evaporated using rotatory evaporator and the samples were placed in small vials and stored in freezer at $-18^{\circ} \mathrm{C}$ for next step. Fatty acids esterification: The esterification of the fatty acids was performed according to the method of Stoffel et al. (1959) which was described by Al-Kaisey et al. (1991). Fatty acids were determined by using Gas Liquid Chromatography (GLC) manufactured by Hewelt - Pakard - 419, USA which is found in Iraqi Nuclear Energy Organization / Baghdad - Iraq.

Statistical Analysis: The complete randomized design (CRD) was used. Statistical difference was determined using Duncan's multiple range test at $(\mathrm{P}<0.05)$ using Statistical Analysis System (SAS) Version (1989).

\section{RESULTS AND DISCUSSIN}

The effect of lactation period or the age of children on the chemical composition of the breast milk: The effect of lactation period or the age of children on the chemical composition of the breast milk was shown on Table (1a,b and c). Results show that there was a significant $(\mathrm{P}<0.05)$ differences in breast milk contents as affected by lactation period. There was increase in $\mathrm{pH}$ value (6.8 and 6.97) during colostrum and transition milk, respectively. Then these values were gradually decreased to keep on steady value until the end of lactation period. Despite that it has been known that the $\mathrm{pH}$ values of the breast milk are increased and decreased during the lactation period (AL-Sarrajy, 1986). The results were in agreement with the results found by Ansell et al. (1977). Therefore, there was no clear effect of lactation period on the $\mathrm{pH}$ of the breast milk. Concerning the fat content of the breast milk, the fat percent was low (2.6\%) during the colostrums and at the beginning of the lactation period (1-3 days after birth and then increased to $3.5 \%$ after $4-15$ days of birth and $3.7 \%$ during the end of the first month (Table 1a and $b$ ). The fat percent was inconsistently increased to reach the value of $4.26 \%$ during the first year of the age of the infant. Consequently, the fat percent was also increased to reach in some samples around $20 \%$ and this might be 
Table (1a): Effect of lactation period on the chemical composition of breast milk.

\begin{tabular}{|c|c|c|c|c|c|c|c|c|c|c|c|c|c|c|c|}
\hline \multirow[t]{2}{*}{ Components \% } & \multicolumn{15}{|c|}{ Lactation period, Child age month } \\
\hline & $\begin{array}{c}1 \\
(n=21)\end{array}$ & $\begin{array}{c}2 \\
(n=16)\end{array}$ & $\begin{array}{c}3 \\
(n=19)\end{array}$ & $\begin{array}{c}4 \\
(n=19)\end{array}$ & $\begin{array}{c}5 \\
(n=16)\end{array}$ & $\begin{array}{c}6 \\
(n=23)\end{array}$ & $\begin{array}{c}7 \\
(n=23)\end{array}$ & $\begin{array}{c}8 \\
(n=23)\end{array}$ & $\begin{array}{c}9 \\
(n=25)\end{array}$ & $\begin{array}{c}10 \\
(n=27)\end{array}$ & $\begin{array}{c}11 \\
(n=24)\end{array}$ & $\begin{array}{c}12 \\
(n=22)\end{array}$ & $\begin{array}{c}13 \\
(n=19)\end{array}$ & $\begin{array}{c}14 \\
(n=16)\end{array}$ & $\begin{array}{c}15 \\
(n=10)\end{array}$ \\
\hline $\mathrm{pH}$ & $\begin{array}{c}6.96 \\
\pm 0.06 \\
\text { bc }\end{array}$ & $\begin{array}{c}6.86 \\
\pm 0.04 \\
\mathrm{bc}\end{array}$ & $\begin{array}{c}6.84 \\
0.07 \\
b c\end{array}$ & $\begin{array}{c}6.81 \\
\pm 0.08 \\
\text { bc }\end{array}$ & $\begin{array}{c}6.86 \\
0.06 \\
\text { bc }\end{array}$ & $\begin{array}{c}6.82 \\
\pm 0.05 \\
\text { bc }\end{array}$ & $\begin{array}{c}6.78 \\
\pm 0.05 \\
\text { bc }\end{array}$ & $\begin{array}{c}6.79 \\
\pm 0.07 \\
\text { bc }\end{array}$ & $\begin{array}{c}6.73 \\
\pm 0.05 \\
\mathrm{bc}\end{array}$ & $\begin{array}{c}6.73 \\
\pm 0.05 \\
\text { bc }\end{array}$ & $\begin{array}{c}6.88 \\
\pm 0.05 \\
\text { bc }\end{array}$ & $\begin{array}{c}6.79 \\
\pm 0.08 \\
\text { bc }\end{array}$ & $\begin{array}{c}6.74 \\
\pm 0.08 \\
\text { bc }\end{array}$ & $\begin{array}{c}6.79 \\
\pm 0.08 \\
\text { bc }\end{array}$ & $\begin{array}{c}6.59 \\
\pm 0.08 \\
\text { c }\end{array}$ \\
\hline Fat & $\begin{array}{c}3.72 \\
\pm 0.31 \\
\text { de }\end{array}$ & $\begin{array}{c}3.11 \\
\pm 0.38 \\
\mathrm{e}\end{array}$ & $\begin{array}{c}4.29 \\
\pm 0.49 \\
\text { de }\end{array}$ & $\begin{array}{c}3.71 \\
\pm 0.42 \\
\text { de }\end{array}$ & $\begin{array}{c}4.18 \\
\pm 0.37 \\
\text { de }\end{array}$ & $\begin{array}{c}3.23 \\
\pm 0.34 \\
\mathrm{e}\end{array}$ & $\begin{array}{c}3.17 \\
\pm 0.23 \\
\mathrm{e}\end{array}$ & $\begin{array}{c}3.46 \\
\pm 0.36 \\
\text { de }\end{array}$ & $\begin{array}{c}4.01 \\
\pm 0.44 \\
\text { de }\end{array}$ & $\begin{array}{c}4.54 \\
\pm 0.41 \\
\text { bcde } \\
\end{array}$ & $\begin{array}{c}3.60 \\
\pm 0.37 \\
\text { de }\end{array}$ & $\begin{array}{c}4.26 \\
\pm 0.42 \\
\text { de }\end{array}$ & $\begin{array}{c}3.62 \\
\pm 0.40 \\
\text { de }\end{array}$ & $\begin{array}{c}3.99 \\
\pm 0.42 \\
\text { de }\end{array}$ & $\begin{array}{c}4.44 \\
\pm 0.73 \\
\text { cde }\end{array}$ \\
\hline Prot & $\begin{array}{c}4.40 \\
\pm 0.83 \\
\text { bc }\end{array}$ & $\begin{array}{c}1.99 \\
\pm 0.18 \\
\text { de }\end{array}$ & $\begin{array}{c}2.52 \\
\pm 0.56 \\
\text { cde }\end{array}$ & $\begin{array}{c}2.04 \\
\pm 0.23 \\
\text { de }\end{array}$ & $\begin{array}{c}1.84 \\
\pm 0.14 \\
\text { de }\end{array}$ & $\begin{array}{c}1.87 \\
\pm 0.13 \\
\text { de }\end{array}$ & $\begin{array}{c}1.89 \\
\pm 0.15 \\
\text { de }\end{array}$ & $\begin{array}{c}1.69 \\
\pm 0.11 \\
\text { de }\end{array}$ & $\begin{array}{c}1.87 \\
\pm 0.11 \\
\text { de }\end{array}$ & $\begin{array}{c}2.04 \\
\pm 0.09 \\
\text { de }\end{array}$ & $\begin{array}{c}1.91 \\
\pm 0.10 \\
\text { de }\end{array}$ & $\begin{array}{c}1.99 \\
\pm 0.12 \\
\text { de }\end{array}$ & $\begin{array}{c}2.31 \\
\pm 0.22 \\
\text { cde }\end{array}$ & $\begin{array}{c}1.90 \\
\pm 0.09 \\
\text { de }\end{array}$ & $\begin{array}{c}2.68 \\
\pm 0.89 \\
\text { cde }\end{array}$ \\
\hline $\mathrm{Lac}$ & $\begin{array}{c}6.28 \\
\pm 0.46 \\
\mathrm{abc}\end{array}$ & $\begin{array}{c}7.16 \\
\pm 0.24 \\
\mathrm{ab}\end{array}$ & $\begin{array}{c}6.34 \\
\pm 0.41 \\
\mathrm{abc}\end{array}$ & $\begin{array}{c}6.04 \\
\pm 0.38 \\
\mathrm{abc}\end{array}$ & $\begin{array}{c}7.02 \\
\pm 0.27 \\
\mathrm{ab}\end{array}$ & $\begin{array}{c}6.74 \\
\pm 0.18 \\
\text { abc }\end{array}$ & $\begin{array}{c}7.03 \\
\pm 0.20 \\
\mathrm{ab}\end{array}$ & $\begin{array}{c}7.03 \\
\pm 0.25 \\
\mathrm{ab}\end{array}$ & $\begin{array}{c}6.88 \\
\pm 0.17 \\
\mathrm{ab}\end{array}$ & $\begin{array}{c}7.0 \\
\pm 0.20 \\
\mathrm{ab}\end{array}$ & $\begin{array}{c}6.52 \\
\pm 0.31 \\
\mathrm{abc}\end{array}$ & $\begin{array}{c}7.02 \\
\pm 0.18 \\
\mathrm{ab}\end{array}$ & $\begin{array}{c}6.76 \\
\pm 0.31 \\
\mathrm{abc}\end{array}$ & $\begin{array}{c}6.99 \\
\pm 0.23 \\
\mathrm{ab}\end{array}$ & $\begin{array}{c}7.54 \\
\pm 0.27 \\
\mathrm{ab}\end{array}$ \\
\hline Ash & $\begin{array}{c}0.23 \\
\pm 0.02 \\
\mathrm{ab}\end{array}$ & $\begin{array}{c}0.21 \\
\pm 0.01 \\
\mathrm{ab}\end{array}$ & $\begin{array}{c}0.18 \\
\pm 0.02 \\
\mathrm{~b}\end{array}$ & $\begin{array}{c}0.26 \\
\pm 0.05 \\
\mathrm{ab}\end{array}$ & $\begin{array}{c}0.20 \\
\pm 0.01 \\
\mathrm{ab}\end{array}$ & $\begin{array}{c}0.21 \\
\pm 0.01 \\
\mathrm{ab}\end{array}$ & $\begin{array}{c}0.22 \\
\pm 0.01 \\
\mathrm{ab}\end{array}$ & $\begin{array}{c}0.21 \\
\pm 0.01 \\
\mathrm{ab}\end{array}$ & $\begin{array}{c}0.21 \\
\pm 0.01 \\
\mathrm{ab}\end{array}$ & $\begin{array}{c}0.21 \\
\pm 0.01 \\
\mathrm{ab} \\
\end{array}$ & $\begin{array}{c}0.21 \\
\pm 0.01 \\
\mathrm{ab}\end{array}$ & $\begin{array}{c}0.21 \\
\pm 0.01 \\
\mathrm{ab}\end{array}$ & $\begin{array}{c}0.20 \\
\pm 0.01 \\
\mathrm{ab}\end{array}$ & $\begin{array}{c}0.20 \\
\pm 0.01 \\
\mathrm{ab}\end{array}$ & $\begin{array}{c}0.22 \\
\pm 0.0 \\
\mathrm{ab}\end{array}$ \\
\hline Moisture & $\begin{array}{c}85.44 \\
\pm 0.80 \\
\mathrm{ab}\end{array}$ & $\begin{array}{c}86.74 \\
\pm 0.64 \\
\mathrm{ab}\end{array}$ & $\begin{array}{c}86.36 \\
\pm 0.61 \\
\mathrm{ab}\end{array}$ & $\begin{array}{c}87.58 \\
\pm 0.71 \\
\mathrm{a} \\
\end{array}$ & $\begin{array}{c}86.64 \\
\pm 0.52 \\
\mathrm{ab}\end{array}$ & $\begin{array}{c}87.50 \\
\pm 0.36 \\
\mathrm{a}\end{array}$ & $\begin{array}{c}87.57 \\
\pm 0.44 \\
\mathrm{a}\end{array}$ & $\begin{array}{c}87.94 \\
\pm 0.60 \\
\mathrm{a} \\
\end{array}$ & $\begin{array}{c}87.94 \\
\pm 0.60 \\
\mathrm{a}\end{array}$ & $\begin{array}{c}85.76 \\
\pm 0.52 \\
\mathrm{ab}\end{array}$ & $\begin{array}{c}87.85 \\
\pm 0.49 \\
\mathrm{a}\end{array}$ & $\begin{array}{c}86.33 \\
\pm 0.53 \\
\mathrm{ab}\end{array}$ & $\begin{array}{c}87.04 \\
\pm 0.57 \\
\mathrm{ab}\end{array}$ & $\begin{array}{c}87.09 \\
\pm 0.57 \\
\mathrm{ab}\end{array}$ & $\begin{array}{c}85.27 \\
\pm 1.36 \\
\mathrm{ab}\end{array}$ \\
\hline
\end{tabular}

Means sharing the same superscript letter within a line are not significantly different $(\mathrm{P}<0.05)$. 
Table (1b): Effect of lactation period on the chemical composition of breast milk continued

\begin{tabular}{|c|c|c|c|c|c|c|c|c|c|c|c|c|c|c|c|}
\hline \multirow[t]{2}{*}{ Components \% } & \multicolumn{15}{|c|}{ Lactation period, Child age month } \\
\hline & $\begin{array}{c}16 \\
(n=8)\end{array}$ & $\begin{array}{c}17 \\
(\mathrm{n}=9)\end{array}$ & $\begin{array}{c}18 \\
(n=11)\end{array}$ & $\begin{array}{c}19 \\
(n=6)\end{array}$ & $\begin{array}{c}20 \\
(n=7)\end{array}$ & $\begin{array}{c}21 \\
(n=6)\end{array}$ & $\begin{array}{c}22 \\
(\mathrm{n}=8)\end{array}$ & $\begin{array}{c}23 \\
(n=7)\end{array}$ & $\begin{array}{c}24 \\
(\mathrm{n}=7)\end{array}$ & $\begin{array}{c}25 \\
(n=6)\end{array}$ & $\begin{array}{c}26 \\
(n=4)\end{array}$ & $\begin{array}{c}27 \\
(n=3)\end{array}$ & $\begin{array}{c}28 \\
(n=2)\end{array}$ & $\begin{array}{c}29 \\
n=1)\end{array}$ & $\begin{array}{c}30 \\
(n=1)\end{array}$ \\
\hline $\mathrm{pH}$ & $\begin{array}{c}6.75 \\
\pm 0.13 \\
\text { bc }\end{array}$ & $\begin{array}{c}6.82 \\
\pm 0.13 \\
\text { bc }\end{array}$ & $\begin{array}{l}6.99 \\
0.09 \\
b c\end{array}$ & $\begin{array}{c}6.97 \\
\pm 0.07 \\
\text { bc }\end{array}$ & $\begin{array}{c}6.60 \\
0.10 \\
\text { bc }\end{array}$ & $\begin{array}{c}6.83 \\
\pm 0.12 \\
\text { bc }\end{array}$ & $\begin{array}{c}6.76 \\
\pm 0.12 \\
\text { bc }\end{array}$ & $\begin{array}{c}7.07 \\
\pm 0.18 \\
\text { b }\end{array}$ & $\begin{array}{c}7.07 \\
\pm 0.011 \\
\text { b }\end{array}$ & $\begin{array}{c}6.90 \\
\pm 0.15 \\
\text { bc }\end{array}$ & $\begin{array}{c}6.95 \\
\pm 0.05 \\
\text { bc }\end{array}$ & $\begin{array}{c}6.87 \\
\pm 0.01 \\
\text { bc }\end{array}$ & $\begin{array}{c}6.9 \\
\pm 0.30 \\
\text { bc }\end{array}$ & $\begin{array}{c}6.8 \\
\pm 0.0 \\
\mathrm{bc}\end{array}$ & $\begin{array}{c}7.9 \\
\pm 0.0 \\
\mathrm{a}\end{array}$ \\
\hline Fat & $\begin{array}{c}4.19 \\
\pm 0.70 \\
\text { de }\end{array}$ & $\begin{array}{c}5.67 \\
\pm 0.93 \\
\text { bcde }\end{array}$ & $\begin{array}{c}3.46 \\
\pm 0.41 \\
\text { de }\end{array}$ & $\begin{array}{c}4.25 \\
\pm 0.92 \\
\text { de }\end{array}$ & $\begin{array}{c}3.87 \\
\pm 1.1 \\
\mathrm{de}\end{array}$ & $\begin{array}{c}5.47 \\
\pm 1.15 \\
\text { bcde }\end{array}$ & $\begin{array}{l}4.81 \\
\pm 1.3 \\
\text { bcde }\end{array}$ & $\begin{array}{c}7.44 \\
\pm 2.42 \\
\mathrm{~b}\end{array}$ & $\begin{array}{c}4.87 \\
\pm 0.86 \\
\text { bcde }\end{array}$ & $\begin{array}{c}5.92 \\
\pm 1.11 \\
\text { bcde }\end{array}$ & $\begin{array}{c}7.3 \\
\pm 1.81 \\
\text { bc }\end{array}$ & $\begin{array}{c}5.47 \\
\pm 0.53 \\
\text { bcde }\end{array}$ & $\begin{array}{c}6.50 \\
\pm 1.0 \\
\text { bcd }\end{array}$ & $\begin{array}{c}20 \\
\pm 0.0 \\
\mathrm{a}\end{array}$ & $\begin{array}{c}4.20 \\
\pm 0.0 \\
\mathrm{de}\end{array}$ \\
\hline Prote & $\begin{array}{c}1.86 \\
\pm 0.22 \\
\mathrm{de}\end{array}$ & $\begin{array}{c}2.27 \\
\pm 0.26 \\
\text { cde }\end{array}$ & $\begin{array}{c}3.06 \\
\pm 1.09 \\
\text { bcde }\end{array}$ & $\begin{array}{c}2.45 \\
\pm 0.34 \\
\text { cde }\end{array}$ & $\begin{array}{c}1.51 \\
\pm 0.23 \\
\mathrm{e}\end{array}$ & $\begin{array}{c}2.25 \\
\pm 0.28 \\
\text { cde }\end{array}$ & $\begin{array}{c}2.18 \\
\pm 0.33 \\
\text { cde }\end{array}$ & $\begin{array}{c}5.11 \\
\pm 1.73 \\
\mathrm{~b}\end{array}$ & $\begin{array}{c}4.07 \\
\pm 1.75 \\
\text { bcd }\end{array}$ & $\begin{array}{c}2.48 \\
\pm 0.27 \\
\text { cde }\end{array}$ & $\begin{array}{c}3.0 \\
\pm 0.37 \\
\text { bcde }\end{array}$ & $\begin{array}{c}2.60 \\
\pm 0.06 \\
\text { cde }\end{array}$ & $\begin{array}{c}2.55 \\
\pm 0.05 \\
\text { cde }\end{array}$ & $\begin{array}{c}15.0 \\
\pm 0.0 \\
\mathrm{a}\end{array}$ & $\begin{array}{c}1.60 \\
\pm 0.0 \\
\mathrm{e}\end{array}$ \\
\hline $\mathrm{Lac}$ & $\begin{array}{c}7.0 \\
\pm 0.35 \\
\mathrm{ab}\end{array}$ & $\begin{array}{c}6.20 \\
\pm 0.81 \\
\mathrm{abc}\end{array}$ & $\begin{array}{c}6.94 \\
\pm 0.63 \\
\mathrm{ab}\end{array}$ & $\begin{array}{c}6.62 \\
\pm 0.38 \\
\text { abc }\end{array}$ & $\begin{array}{c}6.54 \\
\pm 0.88 \\
\mathrm{abc}\end{array}$ & $\begin{array}{c}7.18 \\
\pm 0.40 \\
\mathrm{ab}\end{array}$ & $\begin{array}{c}5.96 \\
\pm 1.01 \\
\text { abc }\end{array}$ & $\begin{array}{c}3.64 \\
\pm 1.06 \\
\mathrm{~d}\end{array}$ & $\begin{array}{c}5.64 \\
\pm 0.86 \\
\text { bc }\end{array}$ & $\begin{array}{c}6.98 \\
\pm 0.81 \\
\mathrm{ab}\end{array}$ & $\begin{array}{c}7.0 \\
\pm 0.74 \\
\mathrm{ab}\end{array}$ & $\begin{array}{c}7.90 \\
\pm 0.31 \\
\mathrm{a}\end{array}$ & $\begin{array}{c}7.20 \\
\pm 0.0 \\
\mathrm{ab}\end{array}$ & $\begin{array}{c}4.80 \\
\pm 0.0 \\
\text { cd }\end{array}$ & $\begin{array}{c}7.50 \\
\pm 0.0 \\
\mathrm{ab}\end{array}$ \\
\hline Ash & $\begin{array}{c}0.20 \\
\pm 0.02 \\
\mathrm{ab}\end{array}$ & $\begin{array}{c}0.22 \\
\pm 0.01 \\
\mathrm{ab}\end{array}$ & $\begin{array}{c}0.20 \\
\pm 0.02 \\
\mathrm{~b}\end{array}$ & $\begin{array}{c}0.21 \\
\pm 0.01 \\
\text { ab }\end{array}$ & $\begin{array}{c}0.23 \\
\pm 0.03 \\
\mathrm{ab}\end{array}$ & $\begin{array}{c}0.23 \\
\pm 0.01 \\
\mathrm{ab}\end{array}$ & $\begin{array}{c}0.21 \\
\pm 0.02 \\
\mathrm{ab}\end{array}$ & $\begin{array}{c}0.19 \\
\pm 0.02 \\
\mathrm{~b}\end{array}$ & $\begin{array}{c}0.18 \\
\pm 0.01 \\
\mathrm{~b}\end{array}$ & $\begin{array}{c}0.17 \\
\pm 0.03 \\
\mathrm{~b}\end{array}$ & $\begin{array}{c}0.19 \\
\pm 0.01 \\
\mathrm{~b}\end{array}$ & $\begin{array}{c}0.27 \\
\pm 0.01 \\
\mathrm{ab}\end{array}$ & $\begin{array}{c}0.29 \\
\pm 0.01 \\
\mathrm{a}\end{array}$ & $\begin{array}{c}0.24 \\
\pm 0.00 \\
\mathrm{ab}\end{array}$ & $\begin{array}{c}0.17 \\
\pm 0.00 \\
\text { b }\end{array}$ \\
\hline Mois & $\begin{array}{c}86.22 \\
\pm 1.33 \\
\text { ab }\end{array}$ & $\begin{array}{c}86.29 \\
\pm 0.77 \\
\text { ab }\end{array}$ & $\begin{array}{c}86.44 \\
\pm 1.26 \\
\text { ab }\end{array}$ & $\begin{array}{c}85.20 \\
\pm 0.77 \\
\text { ab }\end{array}$ & $\begin{array}{c}87.91 \\
\pm 1.85 \\
\mathrm{a}\end{array}$ & $\begin{array}{c}84.95 \\
\pm 1.55 \\
\text { ab }\end{array}$ & $\begin{array}{c}85.90 \\
\pm 2.95 \\
\text { ab }\end{array}$ & $\begin{array}{c}83.41 \\
\pm 3.16 \\
\mathrm{ab}\end{array}$ & $\begin{array}{c}85.61 \\
\pm 0.71 \\
\text { ab }\end{array}$ & $\begin{array}{c}84.60 \\
\pm 1.90 \\
\text { ab }\end{array}$ & $\begin{array}{c}82.78 \\
\pm 1.69 \\
\text { b }\end{array}$ & $\begin{array}{c}85.27 \\
\pm 0.96 \\
\text { ab }\end{array}$ & $\begin{array}{c}83.35 \\
\pm 2.25 \\
\text { ab }\end{array}$ & $\begin{array}{c}60.0 \\
\pm 0.0 \\
\mathrm{~b}\end{array}$ & $\begin{array}{c}86.40 \\
\pm 0.0 \\
\mathrm{ab}\end{array}$ \\
\hline
\end{tabular}

Means sharing the same superscript letter within a line are not significantly different $(\mathrm{P}<0.05)$. 
Table (1c): Effect of lactation period on the chemical composition of breast milk relating to colostrum, transition and mature milk, continued

\begin{tabular}{|l|c|c|c|c|}
\hline Day of lactation & $1-3$ & $4-15$ & 30 & Means 1-900 \\
\hline $\mathrm{pH}$ & 6.80 & 6.97 & 6.96 & 6.82 \\
\hline Fat\% & 2.6 & 3.5 & 3.7 & 4.1 \\
\hline Protein\% & 12.6 & 4.6 & 4.4 & 2.3 \\
\hline Lactose & 4.4 & 5.6 & 6.2 & 6.7 \\
\hline Ash\% & 0.3 & 0.29 & 0.23 & 0.21 \\
\hline Moisture\% & 79.9 & 86.3 & 85.4 & 86.5 \\
\hline
\end{tabular}

due to that the mother was at the end of lactation period and at the same time at another gestation period. With these state of milk condition the total solid (T.S.) was elicited to $40 \%$ including $15 \%$ protein. This inconsistent increase was on the expense of the quantity of the milk with increasing the period of lactation. The fat percent of the mother milk is considered as the most changeable value through the lactation period, rather during the day and through the lactation intervals (U. S. Dept Agric., 1976 and Jensen et al., 1995). Lubetzky et al. (2006) speculated that if higher caloric content of expressed human milk is needed in a specific preterm infant, evening sample, if available, should be used preferentially. There was a significant increase in fat percent during lactation period from the second to sixteenth week (Clark et al., 1982) and fat percent was increased after 1-2 weeks of the birth (Catzel, 1976). Mandel et al. (2005) concluded that human milk expressed by mothers who have been lactating for $>1$ year has significantly increased fat and energy contents, compared with milk expressed by women who have been lactating for shorter periods. Recently, Bishara et al. (2008) found that concentrations of retinol were significantly higher in hindmilk than in foremilk (1.6-fold), as were concentrations of a-tocopherol (1.6-fold), $\gamma$-tocopherol (1.5-fold), fat (1.7-fold), energy (1.3-fold), and nitrogen (1.05fold). Therefore, the fat percent of the breast milk was influenced by lactation period (Guthrie et al., 1977). The above results were in agreement with those found by Jensen et al. (1995) and Ferris et al. (1988); comparable with the result found by Lonnerdal et al. (1976) and little higher than the result found by Lucus et al. (1978).

Table (1c) comprised another component of the breast milk, protein. The protein percent was higher $(12.6 \%)$ during colostrum period then it was reduced to $4.6 \%$ at the period between week 4-15 and 4.4\% through the end of the first month before become constant nearly about $2.3 \%$ through the rest of the lactation period. Al-Sarrajy (1986) found that protein, fat and ash were influenced by lactation period, especially protein depends on this period (Harzer and Bindles, 1985 and 1987). It has been noticed that colostrum contains higher content of immunoproteins and lactoferrin and these were starting to decrease during lactation period (Georgy and Swatziki, 1994). These consistent changes in the composition of the breast milk were required to development of the child growth (Gurr, 1981 and Al-Sarrajy, 1986). These results were in agreement with the results found by Crawford et al. (1977) and Belavady (1987) and comparable with the results observed by Lonnerdal et al. (1976). Some researchers (Atkinson et al., 1978; Georgy and Swatizki, 1994 and Al-Soofy, 1997) were found little lower than these results and this might be due to the differences in sampling in 
which milk at the end of lactation contains 1.3 times the natural content of the protein (Crawford et al., 1977 and Belavady et al., 1987).

Results in Table $(1 \mathrm{c})$ show that there were a significant $(\mathrm{P}<0.05)$ differences in the lactose percent between the lactation periods corresponding with increasing the lactose percent during the lactation period and this was in agreement with the results found by Ferris et al. (1988). They stated that the lactose percent was increased from 6.3 to 7 $\mathrm{g} / 100 \mathrm{ml}$ during 2 to 16 weeks. Similarly, results in Table (1c) show that the colostrum contained $4.4 \%$ lactose and this changed to $5.6 \%$ during $4-15$ days to reach $6.28 \%$ in the end of first month before keep constant nearly about its normal value and this might be due to balance the milk total solid. Coppa et al. (1993) observed that the lactose percent was elevated $17 \%$ through 13 weeks from the delivery. This elevation of lactose of the human milk might be due to the interwoman variation or mother individuality and might be due to the balance requirement of the milk total solid specially between fat, protein and lactose as they required for energy balance and biosyntheses of a new tissues such as nervous system (U. S. Dept. Agric., 1976 and Gross et al., 1981). Similar results were found by other researchers (Miller et al., 1994 and Huisman et al., 1996).

Ash is another component of the breast milk as represents the minerals content of the milk. Table (1c) show the chemical composition of human milk including the ash content. Results show that during the 1-3 days after delivery, colostrum elicited higher $(0.34 \%)$ content of ash and this would decreased to $0.29 \%$ after $4-15$ days of delivery and reached to $0.23 \%$ at the end of the first month. The higher percent of ash in the colostrum might be due to the higher content of immunoprotein which responsible for chelating the minerals. This result was in agreement with other results found by U. S. Dept. Agric. (1976) and Al-Sarrajy (1986). Likely, stage of lactation was inversely correlated with concentration of calcium, total phosphorus, magnesium and sodium (Fly et al., 1998). It has been known that the moisture is the main content of the natural or the fresh milk. Stage of lactation was well correlated with water content. At the beginning of the lactation period and through the colostrum stage the moisture was low (79.9\%) (Table 1c) and this might be due to the higher content of other components of the milk or total solids such as protein and this moisture was increased to reach 86.3 during transition milk. Usually, stage of lactation was associated with moisture variation and this was in agreement with the result of Al-Sarrajy (1986). Previously, Catzel (1976) stated that moisture was increased in the transition milk and after 1-2 weeks of delivery.

The effect of lactation period on fatty acids composition in breast milk: The effect of stage of lactation on the fatty acids composition in human milk was shown in Table (2 and 3). Results show that there was a significant difference between fatty acids percent concurrent with slight increase and decrease in the percentages during the lactation period. Concerning with saturated fatty acids (SAFA), there was clear gradual reduction beginning with the first month (59.59\%) until the sixth month $(51.06 \%)$ before another increase to accomplish the highest percent of $60.69 \%$ during twelfth month and longer (Table 3). These results were little higher than those results found by Jackson et al. (1993) and Huisman et al. (1996). It seems to note that the fatty acids responsible for these values were myristic $(\mathrm{C} 14,10.73 \%)$, palmitic $(\mathrm{C} 16,34.24 \%)$ and 
Mesopotamia J. of Agric. $\quad$ (ISSN 1815-316X) Vol. (38) No. (1) 2010

Table (2): Effect of lactation period on the fatty acids composition of the breast milk.

\begin{tabular}{|c|c|c|c|c|c|c|c|c|c|c|c|c|c|c|c|}
\hline \multirow{2}{*}{$\begin{array}{l}\text { Lactation } \\
\text { period, } \\
\text { Month } \\
\text { postpartum }\end{array}$} & \multicolumn{15}{|c|}{ Fatty acids $\%$} \\
\hline & C6 & $\mathrm{C} 8$ & C9 & $\mathrm{C} 10$ & C12 & $\mathrm{C} 14$ & $\mathrm{C} 15$ & $\mathrm{C} 16$ & C16:1 & $\mathrm{C} 18$ & C18:1 & C18:2 & C18:3 & $\mathrm{C} 20$ & $\mathrm{C} 22$ \\
\hline \multirow{3}{*}{$\begin{array}{c}1^{\text {st }} \\
n=5\end{array}$} & 0.00 & 0.18 & 0.08 & 0.95 & 7.92 & 10.73 & 0.15 & 34.24 & 0.93 & 5.30 & 33.51 & 4.83 & 1.03 & 0.02 & 0.02 \\
\hline & \pm 0.00 & \pm 0.07 & \pm 0.04 & \pm 0.21 & \pm 1.87 & \pm 2.15 & \pm 0.07 & \pm 2.98 & \pm 0.18 & \pm 2.49 & \pm 2.37 & \pm 0.83 & \pm 0.80 & \pm 0.02 & \pm 0.02 \\
\hline & $\mathrm{a}$ & b & $\mathrm{a}$ & $\mathrm{a}$ & $a b$ & $a b$ & $a b$ & $\mathrm{a}$ & b & $\mathrm{a}$ & bc & b & $\mathrm{a}$ & $\mathrm{a}$ & b \\
\hline \multirow{3}{*}{$\begin{array}{c}3 \\
n=6\end{array}$} & 0.10 & 1.16 & 0.07 & 1.42 & 6.90 & 7.55 & 0.10 & 32.97 & 1.42 & 3.62 & 32.39 & 11.15 & 0.89 & 0.10 & 0.11 \\
\hline & \pm 0.10 & \pm 0.80 & \pm 0.03 & \pm 0.48 & \pm 1.39 & \pm 0.72 & \pm 0.03 & \pm 3.11 & \pm 0.38 & \pm 1.04 & \pm 1.51 & \pm 3.57 & \pm 0.32 & \pm 0.06 & \pm 0.06 \\
\hline & $\mathrm{a}$ & $\mathrm{a}$ & bc & $\mathrm{a}$ & $a b$ & b & $a b$ & $\mathrm{a}$ & $\mathrm{a}$ & $\mathrm{a}$ & bc & $\mathrm{a}$ & $\mathrm{a}$ & $a$ & $\mathrm{a}$ \\
\hline \multirow{3}{*}{$\begin{array}{c}6 \\
n=6\end{array}$} & 0.00 & 0.56 & 0.03 & 0.57 & 5.78 & 8.56 & 0.11 & 32.06 & 1.54 & 3.18 & 38.51 & 8.37 & 0.46 & 0.10 & 0.11 \\
\hline & \pm 0.00 & \pm 0.34 & \pm 0.02 & \pm 0.11 & \pm 1.11 & \pm 1.06 & \pm 0.05 & \pm 1.87 & \pm 0.36 & \pm 0.41 & \pm 1.30 & \pm 1.26 & \pm 0.08 & \pm 0.06 & \pm 0.06 \\
\hline & $\mathrm{a}$ & $\mathrm{b}$ & $\mathrm{bc}$ & $\mathrm{a}$ & b & $a b$ & $a b$ & $\mathrm{a}$ & $\mathrm{a}$ & $\mathrm{a}$ & $\mathrm{a}$ & $\mathrm{a}$ & $\mathrm{a}$ & $\mathrm{a}$ & $\mathrm{a}$ \\
\hline \multirow{3}{*}{$\begin{array}{c}9 \\
n=7\end{array}$} & 0.00 & 0.39 & 0.02 & 1.11 & 8.87 & 12.04 & 0.36 & 31.18 & 1.21 & 2.45 & 32.05 & 9.79 & 0.28 & 0.05 & 0.12 \\
\hline & \pm 0.00 & \pm 0.10 & \pm 0.01 & \pm 0.27 & \pm 1.68 & \pm 2.28 & \pm 0.29 & \pm 1.59 & \pm 0.21 & \pm 0.55 & \pm 2.30 & \pm 1.96 & \pm 0.06 & \pm 0.02 & \pm 0.05 \\
\hline & $\mathrm{a}$ & $\mathrm{b}$ & $\mathrm{c}$ & $\mathrm{a}$ & $\mathrm{a}$ & $a b$ & $\mathrm{a}$ & $\mathrm{a}$ & $\mathrm{a}$ & $\mathrm{a}$ & $\mathrm{bc}$ & $\mathrm{a}$ & $\mathrm{a}$ & $\mathrm{a}$ & $\mathrm{a}$ \\
\hline \multirow{3}{*}{$\begin{array}{c}12 \\
n=6\end{array}$} & 0.00 & 2.0 & 0.07 & 1.66 & 9.69 & 12.51 & 0.15 & 30.66 & 0.84 & 3.79 & 30.43 & 7.74 & 0.26 & 0.05 & 0.11 \\
\hline & \pm 0.00 & \pm 1.68 & \pm 0.06 & \pm 0.51 & \pm 1.11 & \pm 0.92 & \pm 0.06 & \pm 2.37 & \pm 0.16 & \pm 0.80 & \pm 1.61 & \pm 1.50 & \pm 0.05 & \pm 0.02 & \pm 0.05 \\
\hline & $\mathrm{a}$ & $\mathrm{a}$ & bc & $\mathrm{a}$ & $\mathrm{a}$ & $\mathrm{a}$ & $a b$ & $\mathrm{a}$ & b & $\mathrm{a}$ & bc & $\mathrm{a}$ & $\mathrm{a}$ & $\mathrm{a}$ & $\mathrm{a}$ \\
\hline
\end{tabular}

Means sharing the same superscript letter within a line are not significantly different $(\mathrm{P}<0.05)$. 
Table (3): Effect of lactation period on the Saturated (SFA), Monounsaturated (MUFA) and Polyunsaturated (PUFA) fatty acids of the breast milk

\begin{tabular}{|l|c|c|c|c|c|}
\hline \multirow{2}{*}{ Fatty acids \% } & \multicolumn{5}{|c|}{ Lactation period, Month postpartum } \\
\cline { 2 - 6 } & $\begin{array}{c}1^{\text {st }} \\
\mathrm{n}=5\end{array}$ & $\begin{array}{c}3 \\
\mathrm{n}=6\end{array}$ & $\begin{array}{c}6 \\
\mathrm{n}=6\end{array}$ & $\begin{array}{c}9 \\
\mathrm{n}=7\end{array}$ & $\begin{array}{c}12 \\
\mathrm{n}=6\end{array}$ \\
\hline SAFA & 59.59 & 54.1 & 51.06 & 56.59 & 60.69 \\
\hline MUFA & 34.44 & 33.81 & 40.05 & 33.26 & 31.27 \\
\hline PUFA & 5.86 & 12.04 & 8.83 & 10.07 & 8 \\
\hline P/S & 0.10 & 0.22 & 0.17 & 0.18 & 0.13 \\
\hline n6/n3, LA/ALA & 4.68 & 12.52 & 18.19 & 34.96 & 29.76 \\
\hline
\end{tabular}

$*$ n6 = omega $(\omega) 6$ fatty acids $n 3=$ omega $(\omega) 3$ fatty acids

LA/ALA $=$ Linoleic acid $/ \alpha$-Linolenic acid

lesser stearic acid $(\mathrm{C} 18,5.3 \%)($ Table 2$)$. Therefore, results show that there was inconsistent correlation between SAFA and the lactation period. Concerning monounsaturated fatty acids (MUFA), data in Table (2 and 3) show that MUFA were more consistent results and slightly close to the average $(34.52 \%)$ during the stage of lactation. Despite that the value was elicited $40.05 \%$ during sixth month of lactation period. This might be due to the mostly one fatty acid, oleic acid (C18:1, 33.51\%) responsibility of this value of MUFA. Polyunsaturated fatty acids were starting with the average value of $5.86 \%$ during first month then it was increased to $12.04 \%$ through the third month before started to decrease to $8 \%$ during 12 month of stage of lactation and the rest of the lactation period in which comparable to the mean value of around 9\%. Data in Table (2) show that the prevalent fatty acid in PUFA value is linolenic acid (C18:2, 4.83\%) during all stage of lactation. Inter fatty acids and inter fatty acids groups variation were a characteristic of the breast milk composition as a requirement for component balance, although it has been to know that there were other factors might be influencing the fatty acids composition included mother nutrition (Thannoun and Abbo, in press). Similar observations were found by Jackson et al. (1993) and Huisman et al. (1996).

It has been known that fatty acids groups likely SAFA and PUFA are interchangeable values as intramolecular content of the human milk, so $\mathrm{P} / \mathrm{S}$ ratio as a parameter was emerged to describe this relationship between acids. Table (3) show that the $\mathrm{P} / \mathrm{S}$ ratio was low (0.09) at the beginning of lactation period (first month) and increased to highest value $(0.22)$ during 3 month of the stage before starting to decrease to elicit the mean value of about 0.13 during first year and later. As we found from Table (2 and 3) P/S ratio was not associated with lactation period. The results were in agreement with other observations found by Boersma et al. (1991), Jackson et al. (1993) and Huisman et al. (1996). Concerning omega fatty acids represented by $\mathrm{n} 6 / \mathrm{n} 3$ ratio were summarized it as the ratio between prevalent $\mathrm{n} 6$ fatty acid was linoleic acid (LA) and prevalent $\mathrm{n} 3$ fatty acid was $\alpha$-linolenic acid ALA (Table 2). Results show that LA percent was ranged between 4.83-11.15\% comparing with 0.26 $1.03 \%$ for ALA during all the lactation period. It seems to note that these ratios were slightly lower than those of other researchers (Harzer et al., 1983 and Huisman et al., 1996). Data in Table (3) show that n6/n3 was lower (4.68) during the first month then 
it was gradually increased to $12.52,18.19$ and 34.96 during respective 3,6 and 9 month of the stage of lactation before dropping little bet to 29.76 during one year and longer. Although, from 10.1 to 23.2 was the $\mathrm{n} 6 / \mathrm{n} 3$ ratio values which detected by Harzer et al. (1983); Guesnet et al. (1993) and Huisman et al. (1996).
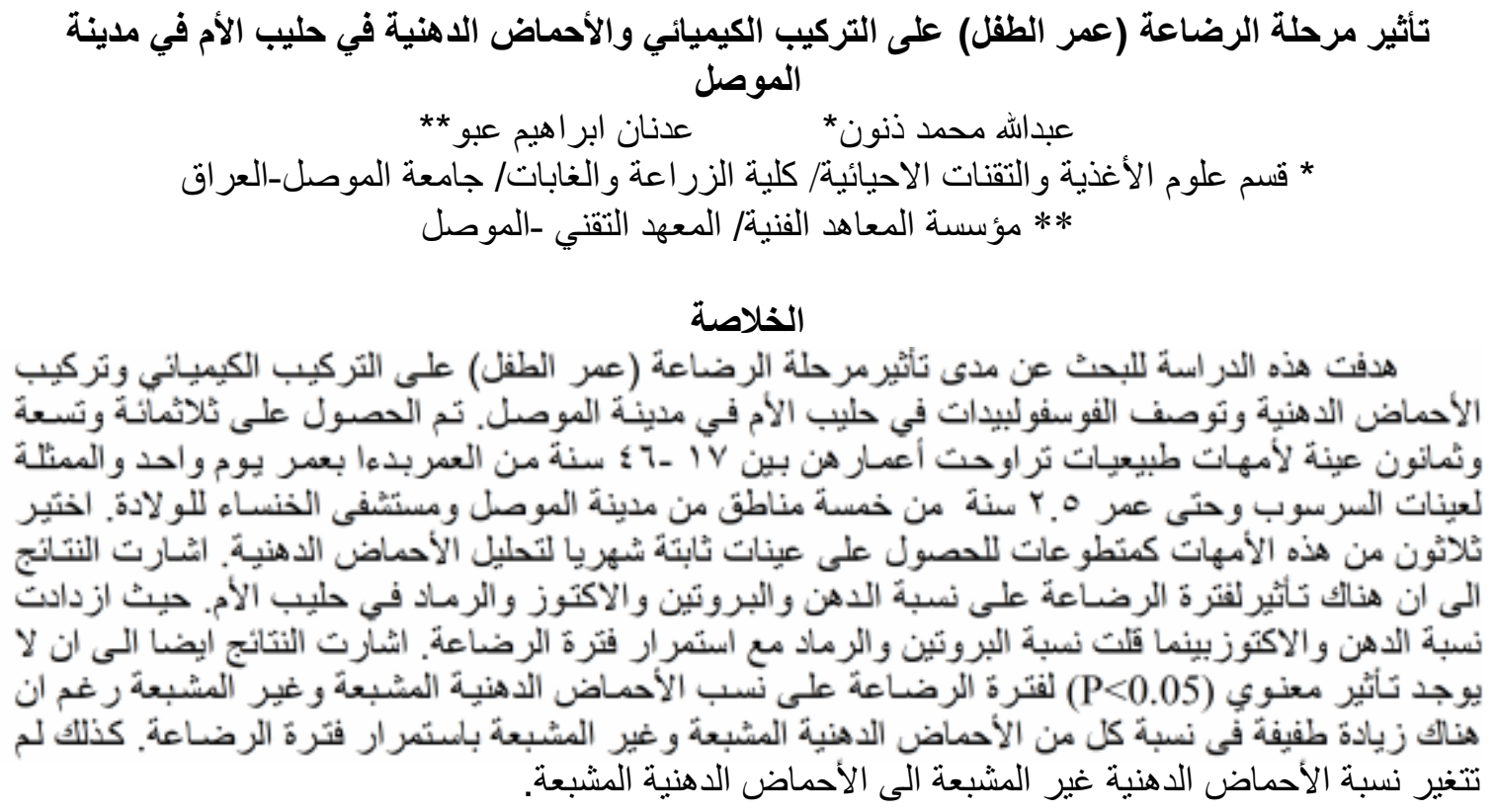

\section{REFERENCES}

Ali, M. M. (1989). Studies on the detailed composition and properties of some constituents of buffalo's milk. PhD Thesis. Faculty of Agric., Ain Shams Univ. Egypt.

Al-Fayadh, M. H. (1973). Some Physico-chemical properties of buffalo milk fat in Iraq. MSc Thesis, Coll. of Agric. Univ. of Baghdad, Iraq.

Al-Hubaity, A. K. H. (1997). Production of low fat-butter and partial substitution with vegetable oils. PhD Thesis. Mosul university, Iraq.

Al-Kaisey, M. T.; H. A. Hadwan; H. M. Saleh and A. A. K. Hussen (1991). Determination of citric acid and oxalic acid in fermented solution of Aspergillus niger by Gas Liquid Chromatography. Iraq J. Microbial. 3: 170-177.

Al-Sarrajy, E. H. (1986). Study the chemical composition of human milk and the effect of some factors. M.Sc Thesis. Coll. of Agric., Univ. of Basra.

Al-Soofi, D. J. (1997). Role of some components of human milk in child resistance to pathogens. M. Sc. Thesis. College of Sciences, Mosul University, Iraq.

Ansell, C.; A. Moore and W. Barrie (1977). Electrolyte and pH change in human milk. Pediatr. Res. 11: 1177-1179.

Atkinson, S. A.; M. H. Bryan and G. H. Anderson (1978) Human milk: difference in nitrogen concentration in milk from mothers of term and preterm infants. J. Pediatr. 93: 67-69.

Belavady, B. (1987). Lipid and trace element compostition of human milk. Acta Pediatr. Scand. 67: 566-571.

Bishara R.; M. S. Dunn; S. E. Merko and P. Darling (2008). Nutrient Composition of Hindmilk Produced by Mothers of Very Low Birth Weight Infants Born at Less Than 28 Weeks' Gestation. J. of Human Lactation 24: 159-167. 
Boersma, E. R.; P. J. Offringa; F. A. J. Muskiet; M. W. Chase and I. J. Simmons (1991). Am. J. Clin. Nutr. 53: 1197-1204. (cited from Prog. Lipid Res. 35: 53-92 (1996).

Catzel, P. (1976). A short text book of pediatrics. Hodder and Storghton Education, Great British.

Clark, R. M.; M. A. Ferris; M. Fey; P. B. Brown; K. E. Anderson and R. G. Jensen (1982). Change in lipids of human milk from 2 to 16 weeks postpartum. J. Ped. Gas. Nutrol. 311-315.

Coppa, G. V.; O. Gabrielli; P. Pierani; C. Catassi; A. Carlucci and P. L. Giorgi (1993). Change in carbohydrate composition in human milk over 4 months of Lactation. Am. Academy of pediatr. 91: 637-641.

Crawford, M. A.; B. M. Laurance and A. E. Munhumbo (1977). Breast feeding and human milk composition. Lancet 1: 99-100.

Eidelman, A. I. (1980). The effect of maternal post conception age on the composition of human breast milk. In human Milk Its Biological and Social value. Publisher by Excerpta media, Amsterdam.

Ferris, A. M.; M. A. Dotts; R. M. Clark; M. Ezrin and R. G. Jensen (1988). Macronutrients in human milk at 2, 12, and 16 weeks postpartum. J. Amer. Diet. Assoc. 88: 694-697.

Fly, A. D.; K. L. Uhlin and J. P. Wallace (1998). Major mineral concentrations in human milk do not change after maximal exercise testing. Am. J. Clin. Nutr. 68: 345-349.

Georgy, R. S. and L. P. Robert (1973). A simplified method for the quantitative assay of small amount of protein in biologic material. Anal. Biochem. 51:654-655.

Georgy, G. and G. Sawatzki (1994). Design of an optimal protein composition for infant nutrition. Act. Pediatric Suppl. 404: 148-155.

Gross, S. J. J. Geller and R. M. Tomarelli (1981). Composition of Breast Milk from Mothers of Preterm Infants. Pediatrics 68: 490-493.

Guesnet, P.; J. M. Antoine; J. B. Rochette delempdis; A. Galent and G. Durand (1993). Polyunsaturated fatty acids composition of human milk in France: Change during the course of lactation and reginal differences. Eur. J. Clin. Nutr. 47: 700-710.

Gurr, M. I. (1981). Human and artificial milk for infant feeding. A Review of the Progress of Dairy Science. J. of Dairy Res. 48: 519-554.

Guthrie, H. A.; M. E. Picciano and D. Seche (1977). J. of Pediatr. 90: 39-41.

Harzer, G. and J. G. Bindels (1985). Changes in human milk immunoglobulin A and lactoferrin during early lactation. Schaub. J. 285-295.

Harzer, G. and J. G. Bindels (1987). Main compositional criteria of human milk and their implication on nutrition in early infancy. Xanthoo. M. (ed) 83-94.

Harzer, G.; M. Hang; I. Dietrich and P. R. Gender (1983). Changing patterns of human milk lipids in the course of the lactation and during one day. Am. J. Clin. Nutr. 37: 612-621.

Huisman, M. ; C. M. Van Beusekon; C. L. Lanting; H. J. Nijebore; F. A. J. Muskier and E. R. Boersma (1996). Triglyceride, fatty acids, sterols, mono and disaccharides and sugar alcohol in human milk and current type of infant formula milk. Eur. J. of Clin. Nutr. 50: 255-260.

Jackson, M. B.; C. J. Lammi-Keefe; R. G. Jensen; S. C. Couch and A. M. ferris (1993). Amer. J. Clin. Nytr. 60:353-361. (cited from Prg. Lipid res. 35:53-92, 1996). 
Jensen, R. G.; J. Bitman; S. E. Carlson; S. C. Couch; M. Hamosh and D. S. Newburg (1995). The Hand Book of milk composition. Ed by Jensen R. G. and Cited from Prog. Lipid Res. 35: 53-92 (1996).

Ling, B. R. (1963). A text book of dairy chemistry. V (11). Chapinan and Hall Ltd. London.

Lonnerdal, A.; E. Forsum; L. Hambraens (1976). Longitudinal study of protein, nitrogen and lactose content of human milk from Swedish will nourished mother. Am. J. Clin. Nutr. 29: 1127.

Lowry, O. H.; N. J. Rosebrough; A. L. Farr and R. J. Randall (1951). The commonly employed method for the quantitative assay of protein. J. Biol. Chem. 193:565.

Lucas, A.; J. A. H. Gibbs and J. D. Baum (1978). Early Human Develop. 2: 351.

Lubetzky R.; Y. Littner; F. B. Mimouni; S. Dollberg and D. Mandel (2006). Circadian Variations in Fat Content of Expressed Breast Milk from Mothers of Preterm Infants. J. Am. Coll. Nutr. 25: 151-154.

Mandel, D. ; R. Lubetzky; S. Dollberg; S. Barak and F. B. Mimouni (2005).Fat and Energy Contents of Expressed Human Breast Milk in Prolonged Lactation. Pediatric 116: e432-e435.

Miller, G. L. (1959). The modification method for quantitative assay of protein. Anal. Chem. 31:264.

Miller, J. B.; S. Bull; J. Miller and P. Mcveagh (1994). The oligosaccharide composition of human milk. Temporal and individual variation in monosaccharide composition. J. Pediatr. Gastro. Nutr. 19: 371-376.

Mohammad, K. I. (1978). The effect of seasons on some lipid constituents of Iraqi buffalo milk concerning quantity and quality. M.Sc. Thesis, University of Baghdad, Iraq.

Plummer, T. D. (1978). An Introduction to practical biochemistry. $2^{\text {nd }}$ Ed. McGrawHill Book Company, England.

Prentice, A. (1996). Constituents of human milk. Food and Nutrition Bulletin. Vol. 17, No. 4.

Russell, C. E. and I. K. Gray (1979). The cholesterol content of dairy products. Newzeland J. Dairy Sci. and Tech. 14: 281-289.

SAS Institute Inc. (1989). Statistical Analysis System. SAS/Stat guide for personal computer. Cary, NC, USA.

Stoffel, W.; F. Ch and E. H. Jr. Ahrens (1959). Analysis of long chain fatty acids by Gas Liquid Chromatography. Micro method for preparation of methyl esters. Anal. Chem. 31: 307-308.

Thannoun, A. M. and A. I. Abbo (In press). The effect of maternal nutritional status on the chemical and fatty acids composition of breastmilk in Mosul City.

U. S. Department of Agriculture (1976). Agricultural Research Service. Agricultural Handbook No. 8-1 (revised). Washington, D. C., USA.

Wagner, C. L. (1999). Human milk as a nutritional and bioactive substance. In Queen, J. T. Ed. Management of high-risk pregnancy, $4^{\text {th }}$ Ed. 537-41.

Walstra, P. and J. J. DeGraff (1962). Note on the determination of the phospholipids content of milk products. Neth. Milk Dairy J. 16: 283-

Williams, S. R. (1985). Nutrition and Dietetic Therapy. $5^{\text {th }}$ Ed. Times Mirror/Mosby College Publishing. St. Louis, USA. 